\title{
Assessment of the severity of acute pancreatitis by contrast-enhanced computerized tomography in 350 patients
}

\author{
Kontrastlı bilgisayarlı tomografi ile akut pankreatitli 350 hastada \\ hastalığın şiddet derecesinin değerlendirilmesi
}

\author{
Mohd Altaf MIR, ${ }^{1}$ Biant Singh BALI, ${ }^{1}$ Riyaz Ahmad MIR, ${ }^{2}$ Hamza WANI ${ }^{1}$
}

\section{BACKGROUND}

This prospective study has been conducted with the aim to assess the severity of acute pancreatitis.

\section{METHODS}

The study included 350 consecutive patients with acute pancreatitis admitted over a period of five years. All these patients were subjected to detailed history and clinical examination and investigations to ascertain the diagnosis. The severity was assessed by contrast - enhanced computed tomography (CT). Data collected were tabulated and subjected to appropriate statistical analysis.

\section{RESULTS}

On the basis of the CT Severity Index (CTSI), the severity of acute pancreatic was classified into Group A (mild), Group B (moderate), or Group C (severe). Group C patients had the most complications (in 77 [91.67\%] patients), and Group A patients had the least (in 7 [6.25\%] patients). Mortality was found to be highest among Group C (14 [16.67\%] patients), indicating the severe nature of disease in these patients, while no mortality was noted in Group A patients. The mean duration of hospital stay of patients in Group A was 9.25 days, Group B 12.0 days and Group C 24.58 days.

\section{CONCLUSION}

The use of contrast-enhanced computed tomography as a routine investigation in patients to predict a severe attack of acute pancreatitis early in the course of the disease decreases overall mortality and burden of disease.

Key Words: Acute pancreatitis; computed tomography severity index; morbidity; mortality.

\begin{abstract}
$A M A C ̧$
$\mathrm{Bu}$ çalışma, akut pankreatitin şiddet derecesini değerlendirmek amaciyla yapıldı.
\end{abstract}

\section{GEREÇ VE YÖNTEM}

Çalışma beş yıllık dönem içinde hastaneye kabul edilen akut pankreatitli ardışı 350 hastayı kapsadı. Tanıyı belirlemek için bu hastaların tümünden ayrıntılı anamnezler alınıp, fiziksel incelemeler ve araştırmalar yapıldı. Hastalığın şiddet derecesi kontrastlı bilgisayarlı tomografiyle (BT) değerlendirildi. Toplanan veriler tablolar halinde gösterilip, uygun istatistiksel analizler yapıldı.

\section{BULGULAR}

BT şiddet derecesi indeksine (BTDI) dayanarak, hastalığın şiddet derecesi A (hafif), B (orta derecede) ve C (şiddetli) grupları şeklinde sınıflandırıldı. En fazla komplikasyon C grubunda ( $\mathrm{n}=77, \% 91,67)$, en az komplikasyon ise A grubunda $(n=7, \% 6,25)$ kaydedildi. $\mathrm{C}$ grubunda ölüm oranlarının en yüksek düzeyde $(\% 16,67)$ saptanmış olması bu hastalarda hastalığın şiddetli seyrettiğine işaret etmektedir. A grubu hastalarında ise hiçbir ölüm olayı kaydedilmedi. Ortalama hastanede kalış süresi A, B ve C gruplarında sırasyyla $9,25,12,0$ ve 24,58 gün idi.

\section{SONUÇ}

Hastalarda, hastalıklarının erken evresinde şiddetli akut pankreatit atağını önceden tahmin amacıyla kontrastlı BT'nin rutin inceleme yöntemi olarak kullanılması genel mortalite ve hastalığın yükünü azaltmaktadır.

Anahtar Sözcükler: Akut pankreatit; bilgisayarlı tomografi hastalığın şiddeti indeksi; morbidite; mortalite. 
In the majority of cases, acute pancreatitis has a mortality of less than $2 \% .{ }^{[1]}$ Despite considerable improvements in treatment, mortality remains between $15 \%$ and $25 \%{ }^{[2]}$ in severe cases and reaches up to $40 \%$ if pancreatic necrosis is infected. ${ }^{[3]}$ Clinical assessment by the clinician is poor in predicting the severity of acute pancreatitis on admission, and it fails to identify up to two-thirds of patients, who eventually develop complications or die. ${ }^{[4]}$ Beneficial results have been obtained with the early management of patients, correctly classified as severe, in intensive care units, with early endoscopic retrograde cholangiopancreatography (ERCP) and biliary drainage in gallstoneinduced disease and prophylactic antibiotics. ${ }^{[5]}$ Criticism of the Atlanta severity classification system is growing, however, because it is retrospective, the duration of organ failure is unspecified, and because local complications do not seem to increase mortality.

${ }^{[6]}$ Ranson Criteria is a clinical scoring system for pancreatitis that takes into account age along with other physiological parameters to determine the severity of pancreatitis. Presence of three or more criteria predicts severe acute pancreatitis. ${ }^{[7]}$ The Acute Physiology and Chronic Health Evaluation II (APACHE II) is the most commonly used severity of illness scoring system in North America. A score of $\geq 8$ points characterizes severe acute pancreatitis. ${ }^{[8]}$ However, the system is complex. For the staging of acute pancreatitis, Balthazar et al. ${ }^{[9]}$ developed a computed tomographic (CT)-based scoring system, in which severity of pancreatitis was graded from A to $\mathrm{E}$ on the basis of pancreatic enlargement and presence of peri-pancreatic fluid collections on un-enhanced CT scan. However, its main drawback was its inability to reliably depict pancreatic necrosis and, consequently, further define the risk of complications in patients with retroperitoneal fluid collections at the time of presentation. A major improvement in the CT grading of pancreatitis was made in 1990, when the Balthazar Computed Tomography Severity Index (CTSI) was introduced, which in addition to the presence of peri-pancreatic fluid collections, took into consideration the presence of pancreatic necrosis, depicted on CT scan as areas of diminished or no enhancement, when oral and intravenous contrast material was given. An excellent correlation was documented between necrosis, length of hospitalization, development of complications, and death. ${ }^{[10]}$

\section{MATERIALS AND METHODS}

This prospective study was conducted in the Department of General Surgery, in collaboration with the Department of Radiodiagnosis and Imaging Government Medical College, Srinagar. The study included 350 consecutive patients with acute pancreatitis who were admitted over a period of five years from 1 June 2006 to 3 May 2011. All these patients were subjected to detailed history and clinical examination and investigations. The severity of acute pancreatitis was assessed by contrast-enhanced computed tomography (CECT). Written and informed consent was taken from all of the patients who were subjected to CECT. Hypersensitivity to contrast material was ruled out and patients were subjected to CECT as per the appropriateness criteria laid down by the American College of Radiology (2001), which were revised in 2006. As per these criteria, the appropriateness of a particular imaging modality in a given clinical setting is rated on a scale of 1 to 9 . A rating of 1 means that a particular imaging modality is least appropriate and a rating of 9 suggests that the investigation is most appropriate in a given clinical scenario. For patients with suspected acute pancreatitis, rating for appropriateness of CT of the abdomen and pelvis is as follows: ${ }^{[1]}$

1: Etiology unknown, first episode of pancreatitis (Rating=6);

2: Severe abdominal pain, elevated serum amylase and serum lipase, no fever or evidence of fluid loss at admission (Rating=7);

3: Severe abdominal pain, elevated serum amylase and serum lipase, 48 hours later assuming no improvement or degradation (assume no prior imaging) (Rating $=8$ );

4: Severe abdominal pain, elevated serum amylase and serum lipase, fever and elevated white blood cell count (Rating=9);

5: Severe abdominal pain, elevated serum amylase and serum lipase, oliguria, tachycardia (Rating=9).

Abdominal CECT was done on a single-slice helical scanner Fxi-GE Medical System, typically 72 hours after admission when it was optimum to rule out pancreatic necrosis and properly delineate the areas of necrosis. Patients were given $20 \mathrm{ml}$ of contrast in 1 liter of water orally 2 hours before the scan. 7 $\mathrm{mm}$ contiguous cuts were taken from the dome of the diaphragm up to the iliac crest after intravenous (IV) administration of $100 \mathrm{ml}$ of $60 \%$ iodinated contrast agent (Lek-Pamidol 300/Iomeron300/Omnipaque) at $1 \mathrm{ml} / \mathrm{sec} 10$. Oral contrast was withheld in patients with vomiting. The CT scan was reported by an experienced radiologist and CTSI, as given below:

Grade of acute pancreas points (Balthazar Score)

$\mathrm{A}=$ Normal pancreas

$\mathrm{B}=$ Pancreatic enlargement alone 1

$\mathrm{C}=$ Inflammation confined to the pancreas and peripancreatic fat

$\mathrm{D}=$ One pancreatic fluid collection

$\mathrm{E}=$ Two or more peripancreatic fluid collections 4 
Degree of pancreatic necrosis

No necrosis

Necrosis of one-third of pancreas (30\%)

Necrosis of one-half of pancreas (50\%)

Necrosis of more than one-half of pancreas 6 $(>50 \%)$

The CTSI was calculated by grade + degree of necrosis points $^{[10]}$ (Table 1).

Patients were divided into three categories:

Group A - Mild (0-3 points) (Fig. 1a)

Group B - Moderate (4-6 points) (Fig. 1b)

Group C - Severe (7-10 points) (Fig. 1c)

The patients were managed according to the standardized protocols of acute pancreatitis and were observed for the development of any complication or any operative intervention needed. Standard operative procedure in our study remained laparotomy with pancreatic necrosectomy (Fig. 1d) and closed lavage. The hospital stay of the patients was noted. Any deaths occurring were recorded. The CTSI was used to predict the morbidity and mortality of patients with acute
Table 1. CTSI vs mortality and morbidity

\begin{tabular}{lcc}
\hline $\begin{array}{l}\text { Severity index } \\
\text { (CTSI) }\end{array}$ & $\begin{array}{l}\text { Predicted } \\
\text { mortality }\end{array}$ & $\begin{array}{c}\text { Predicted } \\
\text { complications }\end{array}$ \\
\hline $0-1$ & $0 \%$ & $0 \%$ \\
$2-3$ & $3 \%$ & $8 \%$ \\
$4-6$ & $6 \%$ & $35 \%$ \\
$7-10$ & $17 \%$ & $92 \%$ \\
\hline
\end{tabular}

pancreatitis and duration of hospital stay. The results were tabulated and subjected to appropriate statistical analysis. To calculate the $p$ value, Fisher's exact test or unpaired t test was used, as and when needed. A $p$ value of $<0.05$ was taken as indicating statistical significance. The following 55 patients were excluded from the study:

1) Patients with known contrast allergy $(n=15), 2)$ Patients with deranged kidney function $(n=16), 3) \mathrm{He}$ modynamically unstable patients $(n=13), 4)$ As per the appropriateness criteria $(\mathrm{n}=11)$.

\section{RESULTS}

The majority of our patients were in the age range of 41-60 years; the average age of male patients was
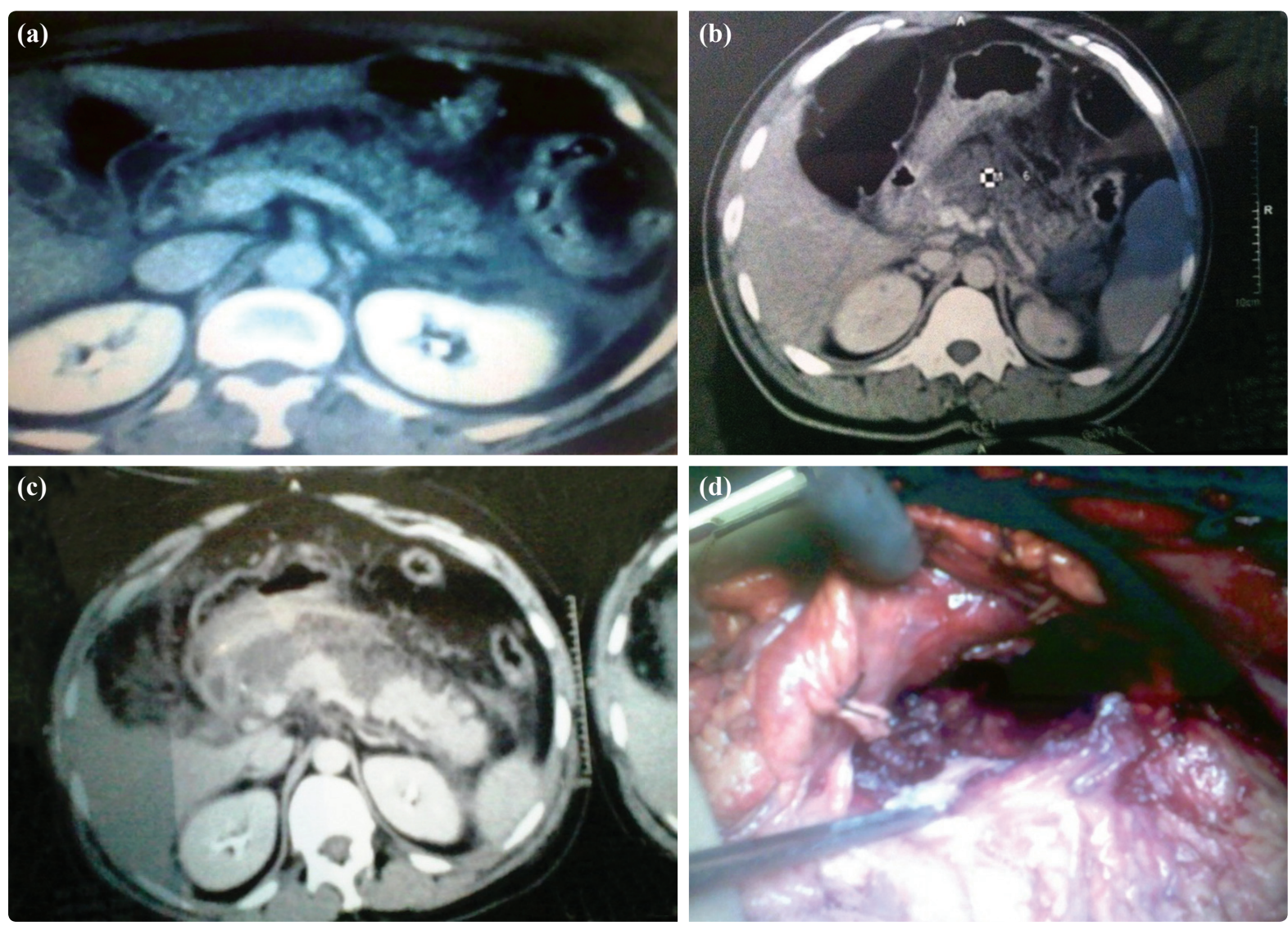

Fig. 1. (a) Bulky pancreas with fat stranding (CTSI 2). (b) Bulky pancreas, peripancreatic fat stranding and fluid collection (CTSI 4). (c) Necrosis of head, neck, body and tail of pancreas (CTSI 9). (d) Pancreatic necrosectomy. (Color figures can be viewed in the online issue, which is available at www.tjtes.org). 
Table 2. CT findings in patients of acute pancreatitis

\begin{tabular}{lc}
\hline CECT findings & $\mathrm{n}(\%)$ \\
\hline Enlarged pancreas & $14(40 \%)$ \\
Peripancreatic fat stranding & $28(20)$ \\
Peripancreatic fluid collection & $308(88 \%)$ \\
$\quad$ Single & $210(60 \%)$ \\
2 or more & $98(28 \%)$ \\
Necrosis & $217(62 \%)$ \\
$\quad$ Nil 30\% & $133(32.29 \%)$ \\
Nil 50\% & $63(18 \%)$ \\
Nil $>50 \%$ & $21(6 \%)$ \\
Emphysematous pancreatitis & $14(4 \%)$ \\
Pancreatic ascites & $84(24 \%)$ \\
Thickened root of mesentery & $35(10 \%)$ \\
Worm in pancreatic duct & $14(4 \%)$ \\
Pleural effusion & $42(12 \%)$ \\
$\quad$ Left & $21(6 \%)$ \\
Right & $7(2 \%)$ \\
$\quad$ Bilateral & $14(4 \%)$ \\
\hline
\end{tabular}

47.71 years and of female patients was 51.48 years. Females were predominant, with a male: female ratio of 1: 1.38. A larger proportion of our patients were from rural areas of Kashmir, with a rural: urban ratio of 1.38: 1. Biliary tract pathology was the predominant etiology. The most common finding on CECT was that of peripancreatic fluid collection, noted in 308 (88\%) patients, and emphysematous pancreatitis, which is often due to infective necrosis, was seen in $14(4 \%)$ of our patients, as revealed by gas in the lesser sac or in the pancreatic substance (Table 2). The mean CTSI observed was 5.9. As shown in Tables 3 and 4, patients in Group $\mathrm{C}$ had the most complications, in 77 (91.67\%) patients, and those in Group A had the least, in 7 $(6.25 \%)$ patients. The $\mathrm{p}$ value was statistically signifi- cant when comparing Group A and Group C patients in terms of complications (p:0.0001). Mortality was found to be highest among Group C, in 14 (16.67\%) patients, indicating the severe nature of their disease, while no mortality was noted in Group A patients (Table 5). The mean duration of hospital stay of patients in Group A was 9.25 days, Group B 12.0 days and Group C 24.58 days. The $\mathrm{p}$ value when comparing the duration of hospital stay between Group A and Group C patients was found to be statistically significant (Table 6). In Group A and B, no patient required operative intervention, whereas among Group C patients, 28 $(25 \%)$ were operated, and $14(50 \%)$ of them expired in the postoperative period (Table 7). The mean surgical intervention time was 21.4 days in Group C.

\section{DISCUSSION}

Acute pancreatitis is a common ailment encountered by surgeons in any part of the world, and it forms a good proportion of emergency admissions in surgical emergency units. Staging of the severity of this disease, with early recognition of severe cases, is essential so that the most suitable treatment can be provided for each patient, with the aims of reducing morbidity, mortality, and duration of hospital stay, thus ensuring important hospital resources are not wasted, especially in a developing country, like ours. Clinical assessment of acute pancreatitis is not reliable, with as many as $50 \%$ of patients being classified incorrectly. It is of utmost importance to assess the diagnosis and severity of acute pancreatitis in the beginning to identify those patients with severe or necrotizing disease who would benefit from an early-initiated intensive care therapy. With regards to morbidity, among patients with a CTSI of 0-1 and 2-3 (mild), complications were present in only $7(6.25 \%)$ patients, whereas among those with CTSI of 4-6 (moderate) $56(36.37 \%)$ had complications, and among those with CTSI of 7-10 (se-

Table 3. CTSI vs mortality and morbidity

\begin{tabular}{lcccc}
\hline Complications & No. of patients & Patients with complications & Percentage & \multicolumn{2}{c}{$p$} \\
\hline Mild (A) & $112(32 \%)$ & 7 & $6.25 \%$ & A vs. B 0.0525 \\
Moderate (B) & $154(44 \%)$ & 56 & $36.37 \%$ & B vs. C 0.0031 \\
Severe (C) & $84(24 \%)$ & 77 & $91.67 \%$ & A vs. C $<0.0001$ \\
\hline
\end{tabular}

Table 4. CTSI vs mortality and morbidity

\begin{tabular}{lcccccc}
\hline Complication & $\begin{array}{c}\text { Pleural } \\
\text { effusion }\end{array}$ & $\begin{array}{c}\text { Acute fluid } \\
\text { collection }\end{array}$ & $\begin{array}{c}\text { Acute } \\
\text { renal failure }\end{array}$ & $\begin{array}{c}\text { Pancreatic } \\
\text { ascites }\end{array}$ & ARDS & Sepsis \\
\hline Mild (A) & $7(6.25 \%)$ & $0(0 \%)$ & $0(0 \%)$ & $0(0 \%)$ & $0(0 \%)$ & $0(0 \%)$ \\
Moderate (B) & $21(13.64 \%)$ & $21(13.64 \%)$ & $7(4.55 \%)$ & $7(4.55 \%)$ & $0(0 \%)$ & $0(0 \%)$ \\
Severe (C) & $14(16.66 \%)$ & $14(16.66 \%)$ & $21(25 \%)$ & $14(16.66 \%)$ & $7(8.33 \%)$ & $7(8.33 \%)$ \\
\hline
\end{tabular}

ARDS: Acute respiratory distress syndrome. 
Table 5. CTSI vs mortality

\begin{tabular}{lccccc}
\hline Mortality & No. of patients & Patients expired & Percentage & \multicolumn{2}{c}{$p^{*}$} \\
\hline Mild (A) & 112 & 0 & $0 \%$ & A vs. B & 1.000 \\
Moderate (B) & 154 & 7 & $4.5 \%$ & B vs. C & 0.2794 \\
Severe (C) & 84 & 14 & $16.67 \%$ & A vs. C & 0.1746 \\
\hline
\end{tabular}

Table 6. CTSI vs mortality and morbidity

\begin{tabular}{lcccc}
\hline Hospital stay (days) & No. of patients & Mean \pm SD & SEM & $p^{*}$ \\
\hline Mild (A) & 112 & $9.250 \pm 3.000$ & 0.7500 & A vs. B $<0.05$ \\
Moderate (B) & 154 & $12.000 \pm 1.877$ & 0.4002 & B vs. C $<0.001$ \\
Severe (C) & 84 & $24.583 \pm 4.441$ & 1.282 & A vs. C $<0.001$ \\
\hline
\end{tabular}

SD: Standard deviation; SEM: Standard error of mean.

Table 7. CTSI vs mortality and morbidity

\begin{tabular}{lccc}
\hline Group & No. of cases & Surgical intervention & Mortality \\
\hline Mild (A) & 112 & $0(0 \%)$ & $0(0 \%)$ \\
Moderate (B) & 154 & $0(0 \%)$ & $0(0 \%)$ \\
Severe (C) & 84 & $28(25 \%)$ & $14(50 \%)$ \\
\hline p: $0.0242 ;$ Relative risk: 1.50 ; Remarks - Significant. & &
\end{tabular}

vere), 77 (91.67\%) had complications, indicating an increasing trend towards occurrence of complications, varying in nature, in conjunction with an increase in severity grade as determined on CTSI. Our study is comparable to that of Balthazar, ${ }^{[10]}$ who noted morbidity of $0 \%$ in patients with CTSI of $0-1,8 \%$ in patients with CTSI of $2-3,35 \%$ in patients with CTSI of $4-6$, and $92 \%$ in patients with CTSI of 7-10; that of Ros ${ }^{[1]}$ and Vriens ${ }^{[12]}$ who observed a morbidity of $100 \%$ with CTSI of 7-10; and that of Chisty, ${ }^{[13]}$ who noted morbidity of $100 \%$ in patients with severe pancreatitis (CTSI 7-10). The various complications noted in our patients belonging to the severe group (84 [24\%]), in order of frequency, were azotemia 21 (25\%), pleural effusion $14(16.7 \%)$, pancreatic ascites 14 (16.66\%), acute fluid collection 14 (16.66\%), acute respiratory distress syndrome (ARDS) 7 (8.33\%), and sepsis 7 $(8.33 \%)$. None of our patients had pancreatic abscess. Overall, the most common as well as the most common extrapulmonary complication was pleural effusion, in $42(12 \%)$ of the cases, which was also reported by Wongnai Anchalee et al. ${ }^{[14]}$ Beger et al. ${ }^{[15]}$ noted pancreatic edema $(71 \%)$ as the most common complication. Viedma et al., ${ }^{[16]}$ Lankisch et al., ${ }^{[17]}$ Toh et al., ${ }^{[18]}$ and Heath et al. ${ }^{[19]}$ noted that respiratory failure was the most common type of organ failure in acute pancreatitis, but in our study, the acute renal failure in $28(8 \%)$ cases was the most common organ failure observed. In our study, we found a mortality of $0(0 \%)$ in patients with CTSI of $0-1$ and $2-3$ (mild), of $7(4.5 \%)$ in patients with CTSI of 4-6 (moderate) and of $14(16.67 \%)$ in patients with CTSI of 7-10 (severe), revealing an increasing trend towards mortality with an increase in CTSI, which was also observed by Balthazar, ${ }^{[10]}$ Simchuk et al., ${ }^{[20]}$ Bradley, ${ }^{[21]}$ and Vriens. ${ }^{[12]}$ The mean duration of hospital stay (SD) of patients in Group A was 9.25 (3) days, Group B 12.0 (1.87) days and Group C 24.58 (4.44) days, and hence, the duration of hospital stay increased with the severity, which was also observed by Balthazar, ${ }^{[0]}$ Balthazar, ${ }^{[10]}$ Chisty, ${ }^{[13]}$ and Wongnai Anchalee ${ }^{[22]}$ in their studies. Operative intervention in the form of laparotomy with pancreatic necrosectomy (Figure 4) and closed lavage was required in $28(25 \%)$ of our patients in Group C. The need for abdominal exploration was on the basis of the presence of necrosis with clinical signs of infection, emphysematous pancreatitis on CT scan, and failure of medical management, and the decision was further reinforced by clinical deterioration of the patients, indicated by increase in pulse rate, decrease in blood pressure and silent abdomen. Patients were subsequently managed in the surgical intensive care unit. Fourteen $(50 \%)$ of the operated patients died, due to uncontrolled sepsis and ARDS (in 7 patients each). The higher rate of surgical intervention and postoperative mortality in severe acute pancreatitis observed in our study was also published by Simchuck et al., ${ }^{[20]}$ Shah et al. ${ }^{[23]}$ and Sivsankar. ${ }^{[24]}$

In conclusion, in this study, it was shown that the CECT can prognosticate patients with acute pancreatitis, predict morbidity, mortality and the duration of 
hospital stay in patients with acute pancreatitis, and predict which patients may require surgical intervention to prevent the progression of disease and the likelihood of postoperative mortality. Since improved outcome in the severe form of acute pancreatitis is based on early identification of disease severity and subsequent focused management of these high-risk patients, we advocate the use of CECT as a routine investigation in patients of acute pancreatitis in order to predict a severe attack of acute pancreatitis early in the course of disease, and thus decrease overall mortality and burden of disease.

Conflict-of-interest issues regarding the authorship or article: None declared.

\section{REFERENCES}

1. Steinberg W, Tenner S. Acute pancreatitis. N Engl J Med 1994;330:1198-210.

2. Fernández-Cruz L, Navarro S, Valderrama R, Sáenz A, Guarner L, Aparisi L, et al. Acute necrotizing pancreatitis: a multicenter study. Hepatogastroenterology 1994;41:185-9.

3. Beger HG, Isenmann R. Surgical management of necrotizing pancreatitis. Surg Clin North Am 1999;79:783-800.

4. Wilson C, Heath DI, Imrie CW. Prediction of outcome in acute pancreatitis: a comparative study of APACHE II, clinical assessment and multiple factor scoring systems. Br J Surg 1990;77:1260-4.

5. Nordback I, Sand J, Saaristo R, Paajanen H. Early treatment with antibiotics reduces the need for surgery in acute necrotizing pancreatitis-a single-center randomized study. J Gastrointest Surg 2001;5:113-20.

6. Isenmann R, Rau B, Zoellner U, Beger HG. Does the atlanta classification of severe acute pancreatitis really correlate with outcome in patients with pancreatic necrosis? Gastroenterology 2001;120 Suppl. 1:A485-6.

7. Ranson JH, Rifkind KM, Roses DF, Fink SD, Eng K, Spencer FC. Prognostic signs and the role of operative management in acute pancreatitis. Surg Gynecol Obstet 1974;139:69-81.

8. Khan AA, Parekh D, Cho Y, Ruiz R, Selby RR, Jabbour N, et al. Improved prediction of outcome in patients with severe acute pancreatitis by the APACHE II score at 48 hours after hospital admission compared with the APACHE II score at admission. Acute Physiology and Chronic Health Evaluation. Arch Surg 2002;137:1136-40.

9. Balthazar EJ, Ranson JH, Naidich DP, Megibow AJ, Caccavale R, Cooper MM. Acute pancreatitis: prognostic value of CT. Radiology 1985;156:767-72.

10. Balthazar EJ, Robinson DL, Megibow AJ, Ranson JH. Acute pancreatitis: value of CT in establishing prognosis. Radiology 1990;174:331-6.

11. Ros PR, Bree RL, Foley WD, Gay SB, Glick SN, Heiken JP, et al. Expert panel on gastrointestinal imaging. In: Acute pancreatitis. Reston (VA): American College of Radiology (ACR); 2006.

12. Vriens PW, Linde P, Warmerdon PE. Computed Tomography Severity Index is an early prognostic tool for acute pancreatitis. Journal of American College of Surgeons 2004;201:497502.

13. Chisty IA, Vaqar B, Sajida P, Dawar B, Zishan H. Role of CT in acute pancreatitis and it's complications among age groups. Journal of Pakistan Medical Association 2005;55:431-5.

14. Wongnai A, Mai WNC. Computed Tomography findings of acute pancreatitis in Maharaj Nakorn Chiang Mai Hospital. Chiang Mai Medical Journal 2007;46:45-91.

15. H. G. Beger, B. Rau, J. Mayer, U. Pralle. Natural course of acute pancreatitis. World Journal of Surgery 1997;21:130-5.

16. Viedma JA, Pérez-Mateo M, Agulló J, Domínguez JE, Carballo F. Inflammatory response in the early prediction of severity in human acute pancreatitis. Gut 1994;35:822-7.

17. Lankisch PG, Pflichthofer D, Lehnick D. Acute pancreatitis: which patient is most at risk? Pancreas 1999;19:321-4.

18. Toh SK, Phillips S, Johnson CD. A prospective audit against national standards of the presentation and management of acute pancreatitis in the South of England. Gut 2000;46:23943.

19. Heath D, Alexander D, Wilson C, Larvin M, Imrie C, McMahon $\mathrm{M}$. Which complications of acute pancreatitis are most lethal? A prospective multi-centre clinical study of 719 episodes. Gut 1995;36:A478.

20. Simchuk EJ, Traverso LW, Nukui Y, Kozarek RA. Computed tomography severity index is a predictor of outcomes for severe pancreatitis. Am J Surg 2000;179:352-5.

21. Bradley EL 3rd, Murphy F, Ferguson C. Prediction of pancreatic necrosis by dynamic pancreatography. Ann Surg 1989;210:495-504.

22. Edison de Oiveira FF, Shigweoka D, Bilkar D, Yansada AF. Reproducibility in the assessment of acute pancreatitis with computed tomography. Radiol Bras 2007:383-7.

23. Shah SSH, Ansari MA, Ali S. Early prediction of severity and outcome of acute severe pancreatitis. Pak J Med. Sci 2009;25:619-23.

24. Sivasankar A, Kannan DG, Ravichandran P, Jeswanth S, Balachandar TG, Surendran R. et al. Outcome of severe acute pancreatitis: is there a role for conservative management of infected pancreatic necrosis? Hepatobiliary Pancreat Dis Int 2006;5:599-604. 